\title{
EFFECT OF CLOVERS INTERCROPPING AND EARTHWORM ACTIVITY ON WEED GROWTH
}

\author{
Mohammad Javad Zarea ${ }^{1}$, Amir Ghalavand², Ebrahim Mohamadi Goltapeh ${ }^{3 *}$, Farhad Rejali \\ ${ }^{1}$ Department of Agronomy, College of Agriculture, Ilam University, P.O. Box 69315516, Ilam, Iran \\ ${ }^{2}$ Department of Agronomy, College of Agriculture, Tarbiat Modares University, P.O. Box 14115-336, Tehran, Iran \\ ${ }^{3}$ Department of Plant Pathology, College of Agriculture, Tarbiat Modares University, P.O. Box 14115-336, Tehran, Iran \\ ${ }^{4}$ Soil and Water Research Institute, Tehran, Iran
}

Received: June 16, 2010

Accepted: September 26, 2010

\begin{abstract}
Forage legumes are used to enhance soil fertility of the agroecosystem. Understanding their effect on the agroecosystem during their growing period is essential. The objective of this field study was to evaluate annual clovers intercropping and earthworm activity on the growth of weeds. The field experiment was carried out during the 2006-2007 growing seasons at the research farm of the Seed and Plant Improvement Institute, Karaj (Iran) involving various mixed cropping ratios of berseem clover (Trifolium alexandrinum L., B) and Persian clover (Trifolium resupinatum L., P) (B : P = 1: 0, $3: 1,1: 1,1: 3$ ) with and without earthworm Pheretima sp. inoculation. Nitrogen content of plants and weeds as well as biomass was measured. Forage yield was higher in 2006 than 2007 but had similar response to cropping systems and earthworm inoculation. Total forage yield was highest in mixed cropping system (MCS). While in the first cut, the berseem sole crop (SC) tended to greatly suppress the growth of weeds, in the second cut Persian clover sole crop further suppressed weeds. The greater total crop biomass had an even higher weed suppression. Earthworm activity did not affect cut 1 but increased forage and weed biomass yield in cut 2 . However in cut 1, berseem tended to greatly suppress the growth of weeds, which may be explained by the greater nitrogen accumulation in monocultures and intercrops, Persian clover in cut 2 had greater suppression on weed biomass production. Nitrogen accumulation of crops and weed increased under earthworm activity in the second cut.
\end{abstract}

Key words: weed management, berseem clover, Persian clover, cropping system, earthworm

\section{INTRODUCTION}

For agronomic purposes, weeds are naturally occurring plants that are injurious in agricultural systems (Worsham 1991). Weeds may increase insect and disease damage to crops, decrease the quality of the crop, or even harm the health of animals that ingest them (Janick et al. 1981).

In Iran, chemicals have become the weed control strategy employed most frequently, despite the fact that many weeds are becoming resistant to many important herbicides and creating water and environment pollution. The low cost of herbicides compared to other strategies encourage framers to use the chemical method to control weeds. An important control method under investigation as a way to reduce dependence on chemical control is the use of intercropping (Liebman and Dyck 1993).

Intercropping is the simultaneous growing of two or more crop species in the same field. Light, water and nutrients may be more completely absorbed and converted to crop biomass by intercropping. It is the result of differences in the competitive ability for growth factors between intercropping components (Anil et al. 1998; Ofori and Stern 1987; Willey 1979). In terms of competition this means that the components are not competing for the same ecological niches, and that interspecies competition is weaker than intraspecifc competition for a given factor (Vandermeer 1989).

Efficient utilization of available growth resources is fundamental for achieving sustainable systems of agricultural production. However, during the last 50 years agricultural intensification has taken place as reflected in plant breeding, mechanization, fertilizer and pesticide use. Since intensification intercropping has disappeared from many farming systems (Hauggaard et al. 2001). The main values of forage legumes in cropping systems are their ability to fix atmospheric $\mathrm{N}$ and act as break crops in cereal-rich rotations. However, a major concern for farmers growing legumes in low-input agricultural systems is the inability of the legumes to compete with the weeds (Liebman and Dyck 1993). However, the intent of this objective was not to investigate the influence of intercropping systems on weed controls. Similar results have been published by many authors and do not give novel results. But, the intent was see if cropping systems (which use or do not use earthworm inoculation), that produce more available $\mathrm{N}$ and may lead to a reduction in fertilizer- $\mathrm{N}$ 
used on a subsequent crop while maintaining current weeds control levels, would be useful in sustainable agriculture systems

Berseem clover (Trifolium alexandrinum L.) and Persian clover (Trifolium resupinatum L.) are annual leguminous forage or cover crop species, well adapted to the semiarid conditions of Mediterranean areas. They are high-yielding, nutritious, cool-season forage crops (Knight 1985), grown in pure stands or in mixtures with annual grass species for overwinter grazing and for harvested forage in spring (Martiniello 1999; Stringi et al. 1987). They can be grazed or cut for fodder 2-5 times a year, from late autumn to late spring in average seasons (if sown in early March), up to six times when irrigated, and twice as a summer crop (Zarea et al. 2008, 2009).

Earthworms (Ew) are an important component of the soil system, and can enhance plant growth by improving soil fertility and nutrient cycling (Lee 1985). Enhanced N mineralization is the best documented mechanism which Ew use and is generally thought to be the most important (Curry and Byrne 1992; Lavelle et al. 1992; Subler et al. 1997; Scheu 2003; Brown et al. 2004). Earthworms increase mineralization of the soil organic matter, which increases nutrient availability (Curry and Byrne 1992; Lavelle et al. 1992; Subler et al. 1997).

Among the mechanisms by which earthworms modify plant growth at the individual or community levels (Scheu 2003; Brown et al. 2004), five have been suggested as responsible for the positive effects noted on plant production.

The hypothesis of this research states that (1) intercrops (Persian and berseem clover) will reduce weeds biomass (2) each intercrop system will affect weed control differently (3) intercrop systems will affected N production (4) compotation for nitrogen between each intercrop systems (treatment) and weeds will be different (5) earthworms will affect $\mathrm{N}$ accumulation of crops and the earthworms will affect weeds.

\section{MATERIALS AND METHODS}

\section{Study area and soil property}

Field experiments were conducted at the research farm of the Seed and Plant Improvement Institute, Karaj $\left(54^{\circ} 50^{\prime} \mathrm{N}, 55^{\circ} 35^{\prime} \mathrm{W}\right.$, and $1312 \mathrm{~m}$ above sea level), Iran, during the 2006-2007 dry seasons. The experimental sites were located in a semiarid region. The soil is low in organic matter $(1.08 \%)$. Across the locations, the soil $\mathrm{pH}$ ranges from 7.1 to 7.8 , available phosphorus $(\mathrm{P})$ was $12.21-13.21 \mathrm{mg} / \mathrm{kg}$, available potassium (K) 152-287 kg/ha, cation exchange capacity 8.4-11.0 (CEC), organic matter from 1.08 to $1.017 \%$, earthworms $2.7-3.8$ worms $/ \mathrm{m}^{2}$ at a depth of $5-35 \mathrm{~cm}$.

The experimental design was a factorial experiment in complete randomized design, in three replications. The treatments included five cropping systems (CS): stand ratios of $1: 0\left(84: 0\right.$ plants $\left./ \mathrm{m}^{2}\right), 3: 1$ (63: 21 plants $\left./ \mathrm{m}^{2}\right)$, $1: 1\left(42: 42\right.$ plants $\left./ \mathrm{m}^{2}\right)$, and $1: 3\left(21: 63\right.$ plants $\left./ \mathrm{m}^{2}\right) 0: 1$ (0: 84 plants $\left./ \mathrm{m}^{2}\right)$ of berseem clover to Persian clover (B: P), inoculated with (+) or without (-) Ew (Pheretima sp.). The clover density was 84 plants $/ \mathrm{m}^{2}$. Berseem and Persian clovers were hand seeded at a depth of $1.0-1.5 \mathrm{~cm}$ by surface broadcasting and the seeds were raked into the soil.

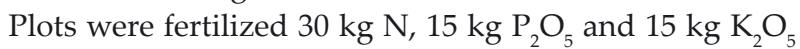
$\mathrm{kg}$ per hectare. The plots were hand weeded. Weeds were not further separated by species. The plots, $3 \mathrm{~m} \times 6 \mathrm{~m}$ in size, were separated by heavy gauge polythene barriers buried to a depth of $0.5 \mathrm{~m}$ into the soil, which stood (initially) $10-15 \mathrm{~cm}$ above the ground. The sowing date was May 18. The clovers were grown with irrigation given at 10-day intervals, at which point water was applied to a height of $65 \mathrm{~mm}$.

Crops and weeds were harvested twice by sickle, at ground level. The first cut, regrowth harvesting (cut 2), and total above-ground biomass yields and weed biomass were recorded. Samples were cut from an inner plant area of $2 \mathrm{~m}^{2}$ at $5-7.5 \mathrm{~cm}$ above the soil level and the clover biomasses were separated by species. The dominant weeds were Amaranthus albus and Polygonum convolvulus.

Shoot samples were oven dried at $70^{\circ} \mathrm{C}$ until daily checks indicated no further reduction in weight. The dried samples were weighed. The dried herbage was ground, passed through a $0.5 \mathrm{~mm}$ screen, and analyzed for $\mathrm{N}$ concentration (Baruah and Barthakur 1997).

Earthworms (Pheretima sp.) were collected by hand from grassland, where the experiments were conducted. The Ew were washed free of surface soil with distilled water and kept in a sterilized glass vessel for $24 \mathrm{~h}$ to minimize the number of naturally occurring arbuscular mycorrhizal fungi (AMF) associated with their surfaces or gut contents. Forty earthworm with similar fresh weight $(0.61 \mathrm{~g})$ and length $(6.2 \mathrm{~cm})$ were added into $\mathrm{m}^{2}$ of soil plots. The population densities of earthworms were similar to that of natural populations near the field experiment (approximately 40 earthworms $/ \mathrm{m}^{2}$ soil).

\section{Data analysis}

The analysis of variance (ANOVA) was performed using SAS software (1990). The significance of the differences between treatments was estimated using the LSD range test, and a main effect or interaction was deemed significant at $\mathrm{p} \leq 0.05$.

\section{RESULTS}

\section{Forage yield and weed biomass}

During the critical periods of germination, crop establishing and flowering development, the maximum daily temperature was noticeably higher in 2007 than in 2006. In 2007, annual rain was lower than 2006. In 2007 there was fair rainfall during spring. However average forage yield at cut 1 and cut 2 were lower in 2007 than 2006 but the yield of both clover species showed a similar trend. This period of higher temperatures may have resulted in poor clover plant being established and poor regrowth (cut 2). The weed biomass in 2007 was higher than in 2006.

At cut 1 , berseem clover in monoculture had a higher forage yield compared to monoculture Persian clover, in both 2006 and 2007. At cut 2, the Persian clover and Berseem clover in monoculture had a similar yield in both 2006 and 2007 (Table 1). The forage yield at cut 1 and cut 2 was significantly $(\mathrm{p} \leq 0.05)$ higher in the MCS compared 
Table 1. Forage yield of single or mixed cropping clovers (P and/or B) inoculated or not inoculated with earthworms, and weed biomass at first cut

\begin{tabular}{|c|c|c|c|c|c|c|c|}
\hline \multirow{3}{*}{ Treatments } & & \multicolumn{6}{|c|}{$\begin{array}{l}\text { Weed biomass and forage yield } \\
{[\mathrm{kg} / \mathrm{ha}]}\end{array}$} \\
\hline & & \multicolumn{2}{|c|}{ Persian clover } & \multicolumn{2}{|c|}{ Berseem clover } & \multicolumn{2}{|c|}{ weed biomass } \\
\hline & & 2006 & 2007 & 2006 & 2007 & 2006 & 2007 \\
\hline \multirow{7}{*}{$\begin{array}{l}\text { Cropping systems } \\
\text { (CS) }\end{array}$} & $0: 1(\mathrm{BP})$ & $966.0 \mathrm{a}$ & $746.33 \mathrm{a}$ & - & - & $1606.0 \mathrm{a}$ & $1565.85 \mathrm{a}$ \\
\hline & $1: 3(\mathrm{BP})$ & $826.417 \mathrm{~b}$ & $724.00 \mathrm{a}$ & $248.5 \mathrm{~d}$ & $170.0 \mathrm{~d}$ & $1491.83 \mathrm{~b}$ & $1451.72 \mathrm{~b}$ \\
\hline & $1: 1(\mathrm{BP})$ & $692.3 \mathrm{c}$ & $589.83 \mathrm{~b}$ & $783.51 \mathrm{c}$ & $698.18 \mathrm{c}$ & $1327.08 \mathrm{c}$ & $1287.07 \mathrm{c}$ \\
\hline & $3: 1(\mathrm{BP})$ & $436.842 \mathrm{~d}$ & $457.67 \mathrm{c}$ & $1405.66 \mathrm{~b}$ & $1323.0 \mathrm{~b}$ & $1168.92 \mathrm{~d}$ & $1287.07 \mathrm{~d}$ \\
\hline & $1: 0(\mathrm{BP})$ & - & - & $1575.46 \mathrm{a}$ & $1489.46 \mathrm{a}$ & $1033.36 \mathrm{e}$ & $993.12 \mathrm{e}$ \\
\hline & LSD 5\% & 17.712 & 30.757 & 1.1412 & 9.97 & 28.015 & 28.56 \\
\hline & F value & 1489.38 & 174.02 & 2607606 & 33878.1 & 608.00 & 585.01 \\
\hline \multirow{2}{*}{$\begin{array}{l}\text { Earthworms } \\
\text { (EW) }\end{array}$} & + Ew & 731.083 & 629.79 & 1003.90 & 922.6 & 1334.34 & 1303.6 \\
\hline & $-E w$ & 729.713 & 629.13 & 1002.6 & 917.6 & 1326.5 & 1266.9 \\
\hline \multirow{3}{*}{$\%$ earthworm } & & 0.187745 & 0.104907 & 0.129663 & 0.5449 & 0.591029 & 2.896835 \\
\hline & LSD 5\% & 12.524 & 21.749 & 0.8069 & 7.05 & 17.71 & 18.06 \\
\hline & F value & 0.06 & 0.001 & 10.60 & 2.29 & 5.46 & 18.16 \\
\hline CS $x$ EW & & n.s. & n.s. & n.s. & n.s. & n.s. & n.s. \\
\hline
\end{tabular}

Values within one column followed by the same liner letter are not significantly $(\mathrm{p} \leq 0.05)$ different; - without earthworm;

+ with earthworm; n.s. - not significant; B - T. alexandrium; $\mathrm{P}$ - T. resupinatum

Table 2. Forage yield of single or mixed cropping clovers (P and/or B) inoculated or not inoculated with earthworms, and weed biomass at second cut

\begin{tabular}{|c|c|c|c|c|c|c|c|}
\hline \multirow{3}{*}{ Treatments } & & \multicolumn{6}{|c|}{$\begin{array}{l}\text { Weed biomass and forage yield } \\
\qquad[\mathrm{kg} / \mathrm{ha}]\end{array}$} \\
\hline & & \multicolumn{2}{|c|}{ Persian clover } & \multicolumn{2}{|c|}{ Berseem clover } & \multicolumn{2}{|c|}{ weed biomass } \\
\hline & & 2006 & 2007 & 2006 & 2007 & 2006 & 2007 \\
\hline \multirow{7}{*}{$\begin{array}{l}\text { Cropping systems } \\
\text { (CS) }\end{array}$} & $0: 1(\mathrm{BP})$ & $5051.7 \mathrm{a}$ & $4718.3 \mathrm{a}$ & - & - & $617.2 \mathrm{e}$ & $603.1 \mathrm{e}$ \\
\hline & $1: 3(\mathrm{BP})$ & $4595.0 \mathrm{~b}$ & $4361.7 \mathrm{~b}$ & $1641.7 \mathrm{~d}$ & $1291.7 \mathrm{~d}$ & $692.5 \mathrm{~d}$ & $714.7 \mathrm{~d}$ \\
\hline & $1: 1(\mathrm{BP})$ & $3025.0 \mathrm{c}$ & $2775.0 \mathrm{c}$ & $2491.6 \mathrm{c}$ & $2141.7 \mathrm{c}$ & $889.8 \mathrm{c}$ & $914.3 \mathrm{c}$ \\
\hline & $3: 1(\mathrm{BP})$ & $1725.0 \mathrm{c}$ & $1641.7 \mathrm{~d}$ & $3241.7 \mathrm{~b}$ & $2891.7 \mathrm{~b}$ & $1150.0 \mathrm{~b}$ & $1174.3 \mathrm{~b}$ \\
\hline & $1: 0(\mathrm{BP})$ & - & - & $5061.6 \mathrm{a}$ & $4711.7 \mathrm{a}$ & $1596.5 \mathrm{a}$ & $1610.3 \mathrm{a}$ \\
\hline & LSD 5\% & 285.3 & 350.1 & 86.6 & 86.6 & 55.4 & 68.6 \\
\hline & F value & 261.5 & 153.7 & 2604.1 & 2604.1 & 453 & 304.2 \\
\hline \multirow{2}{*}{$\begin{array}{l}\text { Earthworms } \\
\text { (EW) }\end{array}$} & $+\mathrm{Ew}$ & $3865.8 \mathrm{a}$ & $3624.2 \mathrm{a}$ & $3320 \mathrm{a}$ & $2970 \mathrm{a}$ & $999.2 \mathrm{a}$ & $1044.2 \mathrm{a}$ \\
\hline & $-\mathrm{Ew}$ & $3332.5 \mathrm{~b}$ & $3124.2 \mathrm{~b}$ & $2898.3 \mathrm{~b}$ & $2548.3 \mathrm{~b}$ & $975.8 \mathrm{~b}$ & $1000.9 \mathrm{~b}$ \\
\hline \multirow{3}{*}{$\%$ earthworm } & & 13.8 & 13.8 & 12.7 & 14.2 & 2.3 & 4.16 \\
\hline & LSD 5\% & 201.8 & 247.6 & 61.2 & 61.2 & 35.1 & 43.4 \\
\hline & F value & 32.1 & 18.7 & 218.2 & 218.2 & 6.2 & 7.1 \\
\hline $\mathrm{CS} \times \mathrm{EW}$ & & n.s. & n.s. & & & n.s. & n.s. \\
\hline
\end{tabular}

Values within one column followed by the same liner letter are not significantly $(\mathrm{p} \leq 0.05)$ different; - without earthworm; + with earthworm; n.s. - not significant; B - T. alexandrium; $\mathrm{P}$ - T. resupinatum

Table 3. Forage total yields of single or mixed cropping clovers ( $\mathrm{P}$ and/ or $\mathrm{B}$ ) inoculated or not inoculated with earthworms at first cut, second cut and total (cut 1 plus cut 2) in 2006 and 2007

\begin{tabular}{|c|c|c|c|c|c|c|c|}
\hline \multirow{2}{*}{$\begin{array}{c}\text { Treatments } \\
\end{array}$} & & \multicolumn{2}{|c|}{$\begin{array}{c}\text { Cut 1 mixtures total yields } \\
{[\mathrm{kg} / \mathrm{ha}]}\end{array}$} & \multicolumn{2}{c|}{$\begin{array}{c}\text { Cut 2 mixtures total yields } \\
{[\mathrm{kg} / \mathrm{ha}]}\end{array}$} & \multicolumn{2}{c|}{$\begin{array}{c}\text { total yields (cut 1 + cut 2) } \\
{[\mathrm{kg} / \mathrm{ha}]}\end{array}$} \\
\cline { 2 - 8 } & 2006 & 2007 & 2006 & 2007 & 2006 & 2007 \\
\hline \multirow{4}{*}{$\begin{array}{c}\text { Cropping systems } \\
\text { (CS) }\end{array}$} & $0: 1$ & $966 \mathrm{e}$ & $746 \mathrm{e}$ & $5051.7 \mathrm{c}$ & $4718 \mathrm{~b}$ & $6017.7 \mathrm{~b}$ & $5464 \mathrm{c}$ \\
\cline { 2 - 8 } & $1: 3$ & $1074.9 \mathrm{~d}$ & $894 \mathrm{~d}$ & $5636 \mathrm{a}$ & $5652 \mathrm{a}$ & $6790.9 \mathrm{a}$ & $6546 \mathrm{a}$ \\
\cline { 2 - 8 } & $1: 1$ & $1475.8 \mathrm{c}$ & $1287 \mathrm{c}$ & $5516 \mathrm{~b}$ & $4259 \mathrm{c}$ & $6991.8 \mathrm{a}$ & $5546 \mathrm{c}$ \\
\cline { 2 - 8 } & $3: 1$ & $1842.4 \mathrm{a}$ & $1780 \mathrm{a}$ & $4966 \mathrm{~d}$ & $4532 \mathrm{bc}$ & $6808.4 \mathrm{a}$ & $6312 \mathrm{a}$ \\
\hline \multirow{2}{*}{ Earthworms (EW) } & $1: 0$ & $1575.4 \mathrm{~b}$ & $1489 \mathrm{~b}$ & $5061 \mathrm{e}$ & $4711 \mathrm{~b}$ & $6636.4 \mathrm{~b}$ & $6200 \mathrm{ab}$ \\
\hline & $-\mathrm{Ew}$ & $850 \mathrm{a}$ & $670 \mathrm{a}$ & $3303.8 \mathrm{a}$ & $4350 \mathrm{a}$ & $6250 \mathrm{a}$ & $5608 \mathrm{a}$ \\
\hline CS & $-\mathrm{Ew}$ & $746 \mathrm{a}$ & $662 \mathrm{a}$ & $2870.4 \mathrm{~b}$ & $4013 \mathrm{~b}$ & $5960 \mathrm{~b}$ & $5405 \mathrm{~b}$ \\
\hline
\end{tabular}

Values within one column followed by the same liner letter are not significantly $(\mathrm{p} \leq 0.05)$ different; - without earthworm; + with earthworm; n.s. - not significant 
to the monocultures (Table 3). The total mixed cropping forage yield of cut 1 and cut 2 were highest in MCS, at $3: 1$ and $1: 3 \mathrm{~kg} / \mathrm{ha}$, respectively, in 2006 (Table 3). Result showed the same trend on forage yield in 2007 (Table 3). Total forage yield (cut 1 plus cut 2) were highest in MCS in 2006. In 2007, Total forage yield (cut 1 plus cut 2) were highest in MCS, at $3: 1$ and $1: 3 \mathrm{~kg} / \mathrm{ha}$ (Table 3). There were no direct interactive effects between CS, and Ew on forage yield. Earthworms had a significant $(p \leq 0.05)$ positive effects on forage yield at cut 2 in both years (Table 1).

At cut 1, the total weed biomass was greater with Persian clover monoculture than various mixture ratios of Berseem and Persian clover and those of the Berseem clover monocultures in both years The weed biomass yield was also significantly $(\mathrm{p} \leq 0.05)$ lower in the monoculture crop $(1: 0)$ than in the mixed crops in the first cut (Table 1$)$. Among the Persian clover intercrop, the biomass yield of weeds increased with reductions in the Berseem clover plants but was significantly lower than that of the Persian clover monoculture crop.

At cut 2, the weed biomass in Berseem clover monoculture had a higher biomass than the Persian clover monoculture in both years. The weeds biomass yield was also significantly $(\mathrm{p} \leq 0.05)$ lower in the monoculture crop $(0: 1)$ than in the mixed crops in the second cut (Table 2). Among the Berseem clover intercrop, the biomass yield of weeds increased with reductions in the Persian clover plants but was significantly lower than that of the Berseem clover monoculture crop (Table 2).

There were no direct interactive effects of Ew on weed biomass at cut 1 in both years. Earthworms had significant $(p \leq 0.05)$ positive effects on weed biomass at cut 2 forage yield in both years. The total weed biomass was the lowest with various mixture ratios of Berseem and Persian clover than those of the monocultures (data not shown).

\section{Nitrogen accumulation}

At cut 1 and cut 2, the berseem clover and Persian clover monocultures had the highest $\mathrm{N}$ uptake, and the Berseem clover monoculture had the highest $\mathrm{N}$ uptake at cut 1 (Fig. 1). At cut 2, the Persian clover monoculture had a higher $\mathrm{N}$ uptake than the Berseem monoculture (Table 4). The Berseem clover $\mathrm{N}$ uptake was also significantly $(\mathrm{p} \leq 0.05)$ higher in the monoculture crop $(1: 0)$ than in the mixed crops in the second cut (Table 4).

The effects of Ew on N uptake was not statistically significant $(\mathrm{p} \leq 0.01)$ at cut 1 . Ew had significantly $(\mathrm{p}<0.001)$ increased $\mathrm{N}$ uptake in crops and weeds in the second cut (Table 3).

At cut 1, the maximum $\mathrm{N}$ uptake for weeds under MCS was $0: 1$ (Fig. 1). At cut 2, the highest $\mathrm{N}$ uptake for weeds under various MCS was $1: 0$ (Table 4).

Table 4. Shoot N-uptake of single or mixed cropping clovers (P and/or B) and weeds inoculated or not inoculated with earthworms at second cut

\begin{tabular}{|c|c|c|c|c|c|c|c|}
\hline \multirow{3}{*}{ Treatments } & & \multicolumn{6}{|c|}{ Nitrogen uptake $[\mathrm{kg} / \mathrm{ha}]$} \\
\hline & & \multicolumn{2}{|c|}{ Persian clover } & \multicolumn{2}{|c|}{ Berseem clover } & \multicolumn{2}{|c|}{ weed biomass } \\
\hline & & 2006 & 2007 & 2006 & 2007 & 2006 & 2007 \\
\hline \multirow{7}{*}{$\begin{array}{l}\text { Cropping systems } \\
\text { (CS) }\end{array}$} & $0: 1(\mathrm{BP})$ & $65.4 \mathrm{a}$ & $63.07 \mathrm{a}$ & - & - & $8.4 \mathrm{~d}$ & $8 \mathrm{~d}$ \\
\hline & $1: 3(\mathrm{BP})$ & $53.7 \mathrm{~b}$ & $52.57 \mathrm{~b}$ & $20.9 \mathrm{c}$ & $15.0 \mathrm{c}$ & $8.6 \mathrm{~d}$ & $8.2 \mathrm{~d}$ \\
\hline & $1: 1(\mathrm{BP})$ & $53.3 \mathrm{~b}$ & $50.38 \mathrm{c}$ & $22.4 \mathrm{c}$ & $15.7 \mathrm{c}$ & $11.2 \mathrm{c}$ & $10.9 \mathrm{c}$ \\
\hline & $3: 1(\mathrm{BP})$ & $39.8 \mathrm{c}$ & $41.33 \mathrm{~d}$ & $37.5 \mathrm{~b}$ & $31.1 \mathrm{~b}$ & $14.2 \mathrm{~b}$ & $13.8 \mathrm{~b}$ \\
\hline & $1: 0$ (BP) & - & - & $62.1 \mathrm{a}$ & $56 a$ & $21.3 \mathrm{a}$ & $1 \mathrm{a}$ \\
\hline & LSD 5\% & 2.5 & 2.01 & 1.3 & 1.8 & 1.4 & 1.4 \\
\hline & F value & 131.5 & 176.74 & 2942.9 & 1455.8 & 133.5 & 130.7 \\
\hline \multirow{2}{*}{$\begin{array}{l}\text { Earthworms } \\
\qquad \text { (EW) }\end{array}$} & $+\mathrm{Ew}$ & $53.9 \mathrm{a}$ & $54.33 \mathrm{a}$ & $39.4 \mathrm{a}$ & $33.7 \mathrm{a}$ & $13.26 \mathrm{a}$ & $13 \mathrm{a}$ \\
\hline & $-E w$ & $51.2 \mathrm{~b}$ & $49.35 \mathrm{~b}$ & $36.6 \mathrm{~b}$ & $30.2 \mathrm{~b}$ & $12.4 \mathrm{~b}$ & $12.1 \mathrm{~b}$ \\
\hline \multirow{3}{*}{ \% earthworm } & & 5.4 & 10.1 & 7.1 & 11.5 & 7.3 & 7.6 \\
\hline & LSD 5\% & 1.8 & 1.4 & 0.9 & 1.3 & 0.9 & 0.9 \\
\hline & F value & 10.4 & 55.1 & 37.6 & 30.7 & 3.6 & 3.6 \\
\hline CS $x$ EW & & n.s. & n.s. & \multicolumn{2}{|c|}{ n.s. } & n.s. & n.s. \\
\hline
\end{tabular}

Values within one column followed by the same liner letter are not significantly ( $\mathrm{p} \leq 0.05)$ different; - without earthworm; + with earthworm; n.s. - not significant ; B - T. alexandrium; $\mathrm{P}-$ T. resupinatum 


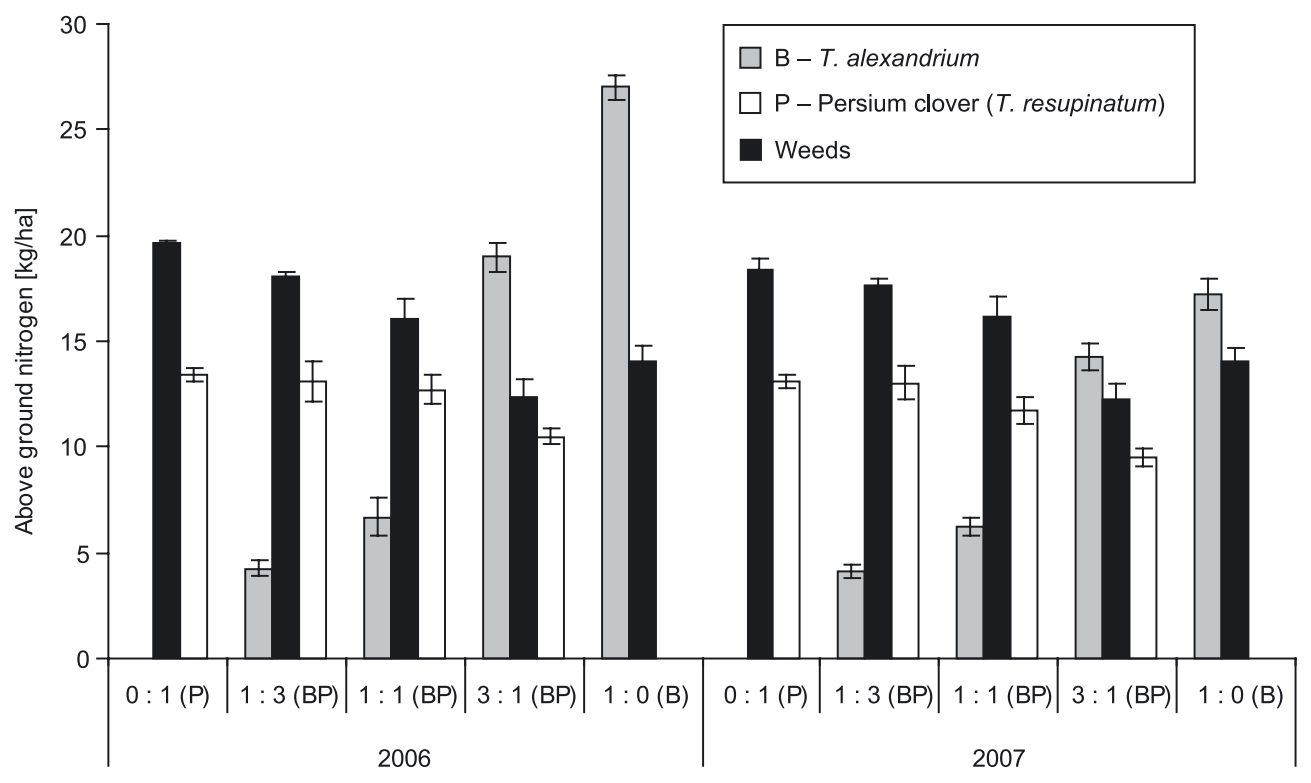

Fig. 1. Shoot N-uptake of single or mixed cropping clovers (P and/or B) and weeds inoculated or not inoculated with earthworms at first cut. Means \pm SE, $p \leq 0.05$

\section{DISCUSSION}

\section{Forage yield and Weed biomass}

Our results indicate the advantage of mixed crops on intercropping forage yields (cut 1 , cut 2). When plant species are intercropped, it is likely that yield advantages occur as a result of the complementary use of resources by the component crops. This advantage is probably due to different above- and below-ground growth habits and morphological characteristics of intercrop components causing a greater efficiency in the utilization of plant growth resources, i.e. water, nutrients and radiation energy (Fukai and Trenbath 1993; Ofori and Stern 1987; Willey 1979). Our results show that the productions of forage berseem clover and Persian clover monocultures were higher than that in the mixed crop cultures (Tables 1,2). This was partly the result of the greater plant populations in the monocrops. Moreover, these crops were not subjected to interspecific competition. At the first cut, the superiority of the forage yields of berseem clover over those of Persian clover was perhaps attributable to a higher number of tillers and branches (data not shown). Despite tiller formation, the higher forage yield of the Berseem clover relative to that of the Persian clover was possibly because of the more rapid accumulation of dry matter in the Berseem clover. Compared with Berseem clover, Persian clover generally has limited growth, especially when subjected to high temperatures. The higher temperatures during cut 1 reduced the growth rate of Persian clover compared with that of Berseem clover, indicating that Berseem clover tolerates high temperatures better. Furthermore, during cut 1 , photosynthesis assimilation in Persian clover compared to Berseem clover better served the roots (data not shown) which help Persian clover regrowth.

At cut 2, the crop experienced interspecific competition. The yield of the Berseem clover was affected by the Persian clover. Although the Persian clover reduced the yield of the Berseem clover, an overall benefit was observed when the yields of both crops were considered together $(1: 3)$. The aboveground dry matter of the Persian clover regrowth increased more during the growth season because of a higher number of tillers and branches compared with those at cut 1 (data not shown).

Result showed that weed biomass differently affected each intercrop system. Different responses of weeds to MSC related to different growth rate and forage yield of clovers species in cut 1 and cut 2 . At cut 1 , Berseem clover had a better ability to reduced incidence of weeds while at cut 2, weeds was better controlled by Persian clover.

Another study indicated the beneficial effect of intercropping on weed control (Anil et al. 1998). But in this study, different habit growth of Persian clover and Berseem clover decreased potential benefits of intercropping on weed control compared to monoculture. But total weed biomass (at cut 1 and cut 2) was the lowest when intercropping was used (data not shown).

Our experiments have shown that the addition of Ew enhanced both the clover shoot yield and weed biomass. But, Ew provided more of a beneficial effect on crops than weeds did. This enhanced forage yield may be related to the physical and chemical improvement of the soil (Kladivko and Timmenga 1990), the production of humic substances that can influence plant growth via physiological effects (Albuzio et al. 1986; Muscolo et al. 1993; Hu et al. 2002), or indirectly to the production of plant growth regulators via the stimulation of microbial activity by the earthworms (Nardi et al. 2002; Quaggiotti et al. 2004; Zarea et al. 2009).

\section{Weeds and forage nitrogen accumulation}

The results of our experiment show that the $\mathrm{N}$ uptake of berseem clover and Persian clover monocultures were higher than that in the mixed crop cultures. This was partly the result of the greater plant populations in the 
monocrops. In the present study, independent of cropping strategy, $\mathrm{B}$ percentage $\mathrm{N}$ accumulation (derived from fixation and soil) was higher compared to $P$ because of higher nodule number and weight as well as nitrogenase activity (data not shown).

The Ew increased the $\mathrm{N}$ uptake of both clovers in mixed and pure crops, which may be attributed to the increased nutrient (especially $\mathrm{N}$ ) availability occurring with the mineralization of the soil organic matter (Curry and Byrne 1992; Lavelle et al. 1992; Subler et al. 1997). The Ew greatest effect was to increase the $\mathrm{N}$ uptake of the clovers when the berseem and Persian clovers were mixed, demonstrating the positive effects of plant diversity and organism combinations.

\section{CONCLUSION}

Clover forage yield was significantly greater with intercropping than in solecropping. There was a significantly greater crop soil $\mathrm{N}$ uptake in intercropping compared to solecropping. At first cut, when growing Berseem clover in intercrop with Persian clover in a ratio of $3: 1$ instead of solecrooping, there was a better competitive ability towards weeds. Thus, the soil inorganic $\mathrm{N}$ was consequently used for Berseem clover forage production instead of weeds biomass. At second cut, when growing Berseem clover in intercrop with Persian clover in a ratio of $1: 3$ instead of sole cropping, there was a better competitive ability towards weeds. This result provides farmers with various opportunities for the development of sustainable food production - with a limited use of external inputs. For example, if a farmer wants to soon devote land to clover crop, use of Berseem clover in a ratio of $3: 1$ is suitable while a long term ratio of $1: 3$ and $1: 1$ would be appropriate. Furthermore, making better use of biological resources for production of food crops can contribute to enhanced sustainability. Earthworms as well as plant species, constitute an important biological resource in this respect. This study showed that by an increased use of the earthworm's biological potential, and suitable crop, the policy to support improvement of soil fertility may be based less on increasing nutrient input through fertilizer programs.

\section{ACKNOWLEDGEMENTS}

We wish to thank Zahra Rashidi for her technical assistance and Mohammad Zamaniyan for his technical assistance, providing initial advice, and for providing seeds.

\section{REFERENCES}

Albuzio A., Ferrari G., Nardi S. 1986. Effects of humic substances on nitrate uptake and assimilation in barley seedings. Can. J. Soil Sci. 66 (4): 731-736.

Anil L., Park R.H.P., Miller F.A. 1998. Temperate intercropping of cereals for forage: a review of the potential for growth and utilization with particular reference to the UK. Grass Forage Sci. 53: 301-317.
Baruah T.C., Barthakur H.P. 1997. A Textbook of Soil Analysis. Vikas Publishing House Pvt. Ltd., New Delhi, India, $334 \mathrm{pp}$.

Brown G.G., Edwards C.A., Brussaard L. 2004. How earthworms affect plant growth: burrowing into the mechanisms. p. 13-49. In: "Earthworm Ecology" (C.A. Edwards, ed.). CRC Press, Boca Raton, USA, 441 pp.

Curry J.P., Byrne D. 1992. The role of earthworms in straw decomposition and nitrogen turnover in arable land in Ireland. Soil Biol. Biochem. 24: 1409-1412.

Fukai S., Trenbath B.R. 1993. Processes determining intercrop productivity and yields of component crops. Field Crops Res. 34 (3-4): 247-271.

Hauggaard N.H., Ambus P., Jensen E.S. 2001. Interspecific competition, $\mathrm{N}$ use and interference with weeds in pea \pm barley intercropping. Field Crops Res. 70 (2): 101-109.

Hu P., Liu D.H., Hu F., Shen Q.R. 2002. Plant hormones in earthworm casts and their promotion on adventitious root formation of mung bean cutting. Acta Ecol. Sin. 22 (8): 12111214.

Janick J., Sherry R.W., Woods F.W., Ruttar V.W. 1981. Plant Science: Introduction to World Crop. WH Freeman, New York, $868 \mathrm{pp}$.

Kladivko E.J., Timmenga H.J. 1990. Earthworms and agricultural management. p. 192-216. In: "Rhizosphere Dynamics" (J.E. Box, L.C. Hammond, eds.). Westview Press, 322 pp.

Knight W.E. 1985. Miscellaneous annual clovers. p. 547-551. In: "Clover Science and Technology" (N.L. Taylor, ed.). Agron. Monogr. 25. ASA, CSSA, and SSSA, Madison, WI, 616 pp.

Lavelle P., Melendez G., Pashanasi B., Schaefer R. 1992. Nitrogen mineralization and reorganization in casts of the geophagous tropical earthworm Pontoscolex corethrurus (Glossoscolecidae). Biol. Fertil. Soils 14 (1): 49-53.

Lee K.E. 1985. Earthworms: their Ecology and Relationships with Soils and Land Use. CSIRO, Sydney, 412 pp.

Liebman M., Dyck E. 1993. Crop rotation and intercropping strategies for weed management. Ecol. Appl. 3 (1): 92-122.

Martiniello P. 1999. Effects of irrigation and harvest management on dry matter yield and seed yield of annual clover grown in pure stand and in mixtures with graminaceous species in a Mediterranean environment. Grass Forage Sci. 54 (1): 52-61.

Muscolo A., Felici M., Concheri G., Nardi S. 1993. Effect of earthi worm humic substances on esterase and peroxidase activity during growth of leaf explants of Nicotiana plumbginifolia. Biol. Fertil. Soils 15: 127-131.

Nardi S., Pizzeghello D., Muscolo A., Vianello A. 2002. Physiological effects of humic substances on higher plants. Soil Biol. Biochem. 34 (11): 1527-1536.

Ofori F., Stern W.R. 1987. Cereal \pm legume intercropping systems. Adv. Agron. 41: 41-90.

Quaggiotti S., Ruperti B., Pizzeghello D., Francioso O., Tugnoli V., Nardi S. 2004. Effect of low molecular size humic subtı stances on nitrate uptake and expression of genes involved in nitrate transport in maize (Zea mays L.). J. Exp. Botany 55 (398): 803-813.

SAS. 1990. SAS Procedure Guide, Version 6, 3rd Edition. SAS Institute, Cary, NC, 705 pp.

Scheu S. 2003. Effects of earthworms on plant growth: patterns and perspectives. Pedobiologia 47: 846-856. 
Stringi L., Amato G., Gristina L. 1987. Trifoglio alessandrino in ambiente semi-arido: influenza dello stadio di utilizzazione e della dose di seme sulla produzione di foraggio e di seme. L'Informatore Agrario 26: 63-68.

Subler S., Baranski C.M., Edwards C.A. 1997. Earthworm addia tions increased short-term nitrogen availability and leaching in two grain crop agroecosystems. Soil Biol. Biochem. 29 (3-4): 413-421.

Vandermeer J. 1989. The Ecology of Intercropping. Cambridge University Press, Cambridge, UK, 237 pp.

Willey R.W. 1979. Intercropping $Đ$ its importance and research needs. Part 1. Competition and yield advantages. Field Crop Abstr. 32 (1): 1-10.

Worsham A.D. 1991. Role of cover crops in weed management and water quality. p. 141-145. In: "Cover C rops for Clean Water" (W.L. Hargrove, ed.). Soil and Water Conservation Society, Ankeny, 196 pp.

Zarea M.J., Ghalavand A., Mohammadi Goltapeh E., Rejali F. 2008. Influence of forage legumes Mixed Cropping on Biomass yield, soil microbial biomass and Nitrogenase activity. Green Farm. J. 1 (6): 12-15.

Zarea M.J., Ghalavand A., Mohammadi Goltapeh E., Rejali F., Zamaniyan M. 2009. Effects of mixed cropping,earthworms (Pheretima sp.), and arbuscular mycorrhizal fungi (Glomus mosseae) on plant yield, mycorrhizal colonization rate, soil microbial biomass, and nitrogenase activity of free-living rhizosphere bacteria. Pedobiologia 52 (4): 223-235.

\section{POLISH SUMMARY \\ DZIAŁANIE MIĘDZYPLONÓW KONICZYN I AKTYWNOŚĆ DŻDŻOWNIC NA WZROST CHWASTÓW}

Paszowe rośliny motylkowe są wykorzystywane do podniesienia żyzności gleby w agrosystemie. Zrozumienie ich działania $\mathrm{w}$ agrosystemie $\mathrm{w}$ czasie wzrostu jest podstawowe. Celem niniejszej pracy była ocena międzyplonu jednorocznych koniczyn i aktywności dżdżownic na wzrost chwastów. W sezonach wegetacyjnych 20062007, przeprowadzono doświadczenie polowe w gospodarstwie doświadczalnym Instytutu Ulepszania Nasion i Roślin Karaj (Iran), uwzględniające różne proporcje mieszanek Triforium alexandrinum L., B i koniczyny perskiej (T. resupinatum $\mathrm{L}$., $\mathrm{P})(\mathrm{B}: \mathrm{P}=1: 0,3: 1$ i $1: 3)$, $\mathrm{z}$ inokulacją dżdżownicami Pheretina sp. lub bez takiej inokulacji. Określono zawartość azotu w roślinach i w chwastach oraz ich biomasę. Plon roślin był wyższy w 2006 r. niż w 2007 r., ale reakcja na systemy uprawy i zaszczepienie dżdżownicami była podobna. Ogólny plon roślin był najwyższy w systemie mieszanej uprawy (MCS). W pierwszym pokosie T. alexandrinum (SC), wystąpiła tendencja dużego ograniczenia chwastów, a w drugim pokosie to ograniczenie było kontynuowane. Przy większej biomasie koniczyny, występowało większe ograniczenie chwastów. Aktywność dżdżownic nie wpływała na pierwszy pokos, ale zwiększała plon biomasy drugiego pokosu. Jednak w pierwszym pokosie koniczyna wykazywała tendencję dużego ograniczenia wzrostu chwastów, co może być tłumaczone większym nagromadzeniem azotu w monokulturze i międzyplonach. Koniczyna perska w drugim pokosie wykazywała większe ograniczenie wytwarzania biomasy chwastów. W drugim pokosie akumulacja azotu w roślinach i aktywność dżdżownic wzrastały. 